\title{
MIGRATION CRISIS - A MAIN PRIORITY FOR THE FIFTH POLISH PRESIDENCY OF THE VISEGRÁD GROUP
}

\author{
Diana IVANOVA \\ “Neofit Rilski” Sout-West University, Blagoevgrad, Bulgaria \\ velevad@abv.bg
}

\begin{abstract}
The migration crisis and related challenges for the future of the Schengen area are some of the main problems facing the EU. The opinion of the Visegrad Four on this issue, however, seriously differs from that of Brussels. Poland, Hungary, the Czech Republic and Slovakia are firmly against the quota principle in the allocation of migrants. The aim of this article is to present the migrant crisis as a top priority during the fifth in the history Polish rotating presidency of the Visegrad Four - from July 1, 2016 to June 30, 2017. This objective will be realized through the implementation of basic tasks analysis of the documents adopted at the forums of the organization, and the views of leading politicians from the Visegrad countries.
\end{abstract}

\section{Keywords: Polish Presidency, Visegrád Group, European Union, migrant crisis}

\section{Introduction}

The Visegrád Group, which was established twenty-seven years ago, has become one of the most successful regional organizations. It has turned into a symbol of a successful initiative for the realization of common interests and it is in the basis of the cooperation in Central Europe. The fifth in the history Polish rotating presidency of the Visegrád Four (V4) - from July 1, 2016 to June 30, 2017, began in a very delicate situation for the EU - immediately after the referendum, for which the British voted that they should be out of the EU, and in terms of the unsolved migrant crisis.

The problem with migrants is undoubtedly the one that to a greater degree affects the countries of the Visegrád Group and represents a major challenge for the Polish Presidency.

Since the presidency is completed soon, there are no fundamental studies on the topic, and the present study is based on the main documents[1], adopted during the Polish Presidency as well as materials from news agencies, connected to the position of V4 on the migration crisis[ ].

The purpose of this article is to analyse the migrant crisis as a top priority of the Polish Presidency of V4. This objective will be realized through the implementation of basic tasks - analysis of the documents adopted at the forums of the organization in the second half of 2016 and the first half of 2017 , and the views of leading politicians from the Visegrád countries.

\section{The Migration Crisis in the Program of the Fifth Polish Presidency of Visegrád Group}

The migration issue and related challenges for the development of the Schengen area are some of the main problems facing the EU. The opinion of the Visegrád Four on this issue, however, seriously differs from that of Brussels. Poland, Hungary, the 
Czech Republic and Slovakia strongly disagree with the quota principle for migrants. What the Czech Presidency of the V4 from 1st July 2015 to 30th June 2016 stated was this categorical position. The role of migrant issue for the Polish Presidency is acknowledged by the position of this problem in the Programme of the Polish Presidency it is ranked first in its first priority, namely "1. STRONG VOICE OF THE V4 IN THE EUROPEAN UNION: coordination of the European agenda and cooperation on key challenges" [3].

To realize this priority the Polish Presidency focuses its activities on the coordination of the position of V4 in EU, resulting in the need to take appropriate decisions to deal with the main reasons for migration, focusing on the effective protection of the external EU borders (including support for third countries). The necessity for joint actions has been established because of the necessity of strengthening, support and maintaining the Schengen countries as one of the basic aspects of the project for European integration [4].

The Visegrád Group is focused on opposing to any actions, supposed to introduce any constant and obligating mechanism, redistribute or considerably limit Member States' ability to influence this region - with regard of the Common European Asylum System's reform, namely the Dublin system. Their struggles are mainly organized towards assistance to other states and developing the relations with them to direct the main reasons for the migration stream [5].

What is intended are the future cooperation within the EU Emergency Trust Fund for stability and directing main reasons for irregular migration and displaced people in Africa. As a donating group, Poland, Hungary, the Czech Republic and Slovakia plan to establish joint positions before summits of the Board and Operational Committees of the Fund.

The Presidency is concerned on the topic for common local humanitarian projects in
Syria and Jordan, which are supposed to be continued, and should be coordinated.

The priorities, discussed at a meeting of interior ministers of Poland, Hungary, the Czech Republic and Slovakia, held on July 11, 2016 in Warsaw, were drawned in the Programme. The agreement on the constructive position of V4 is connected to different sides of refugee and border topics:

1) permanent struggles to reassure appropriate defending of the external borders of the EU countries; 2) improving the assistance to other states; 3) the reducing of agreement for any obligations and determined principles [6].

After the talks, the Polish Interior Minister Mariusz Błaszczak stated that he and his colleagues evaluated negatively the system of automatic refugee resettlement. It is ineffective and unjustified and only attracts new flows of refugees. They declared themselves in favor of support of the refugees in the countries where they already have refugee status - Libya, Jordan, Turkey [7].

This view of the Visegrád Group is indicative of their desire to finish with an issue outside the Old Continent; in this case, xenophobia is not the main aspect, which these states are usually reproved of, but an accurate and reliable international policy [8].

\section{The position of the Visegrád Group on Migration Crisis after the EU Summit in Bratislava}

Poland, Hungary, the Czech Republic and Slovakia decline their position to the quota principle for the settlement of refugees at the meeting of the EU in Bratislava (September 16, 2016). These countries consider defending of external borders of the Schengen area and the whole European Union as one of the most important aspects of their Programme. The defense issue is strongly attached to migration crisis. That is an essential topic for several Member States, five of them. For that reason, V4 is conserned on establishing a refugee policy, based on the principle of "flexible solidarity" [9]. 
The meeting in Bratislava did not achieve any change in the EU migrational policy. Therefore, the Hungarian Prime Minister Viktor Orban estimated it as unsuccessful. He stated that in the EU there continues to prevail a "self-destructive and naive immigration policy" as "on this occasion the summit had focused more on speeding up the process of distributing migrants across Europe than on stopping them at the border of the Schengen Area."[10].

The Hungarian society - as the Prime Minister - also disagreed with the EU policy upon the migration crisis. This tendency results in the referendum, held on the $2^{\text {nd }}$ October $2016-98 \%$ of the Hungarian declined the EU plan for adoption of the obligatory quota of migrants[11]. The referendum results legitimized Orban's policy - the Prime Minister did not aim to "stoke a cultural and political counter-revolution throughout the European Union"[12], as Jan Culik claimed.

The meeting of interior ministers of Poland, Hungary, the Czech Republic and Slovakia, held on November 21, 2016 in Warsaw[13], has an essential influence on the on the realization of the main priority of the fifth Polish Presidency. There, the ministers once again expressed the viewpoint that the concept of effective solidarity[14] should have a specific role in the future debates on migrant issue - not only in V4, but also in EU.

It was announced that a Migration Crisis Response Mechanism - a contra action to the quote system for settlement of migrants - should be created. The center, which will be run by Poland, aims to coordinate more efficintly the institutions, connected to refugees[15]. As a result, there can be a relevant response in providing assistance to refugees in countries outside the European Union. Together with the V4 interior ministers, diplomats, representing Austria, Belgium, Bulgaria, Croatia and Slovenia, participated in the meeting of Visegrad Four. They expressed the opinion that the EU borders should be protected more precisely and the refugees should be returned to their home countries. What they believe in is that plans for resettlement of migrants should be canceled and to pursue a policy of returning refugees who have reached the EU should be pursued. That is considered to be the only way to prevent the migration crisis.

The summit of foreign ministers of Poland, Hungary, the Czech Republic and Slovakia, held on November 29, 2016 in Warsaw, emphasized the illegal migration as one of the most important challenges for Europe. The High Representative of the Union for Foreign Affairs and Security Policy and the Vice-President of the European Commission Federica Mogherini attended the meeting[16]. There, the Ministers of V4 confirmed their assistance for the European intensions in the Western Balkans countries. For that reason, they established a common declaration on the European Union expanding. They distinguished the responsible and efficient policy of expanding as a basic investment for European defense[17].

The prime ministers of V4 also pointed out the prime role of resolving the migration crisis in their Joint Statement at the Council of Europe meeting in Brussels on 15 December 2016. V4 welcomed the concern of the European Council in December on main difficulties that the European Union is supposed to face.

V4 appreciate important struggles of the Slovak Presidency of the Council of the EU (during the second half of 2016) to expand the agreement, connected to the principles of solidarity and reliability in the situation of refugee policy. They analyse the progress in the convergence of views on different points, including the external dimension of migration and the defense of external borders of European Union. Meanwhile, another struggle is needed to result in consensus on the foreign policy dimension of migrational situation. V4 is ready to expand the efforts towards this aim. They believe that any new European migration policy can only be built for a 
joint region where the main control of external borders is ensured and, therefore, migratory stream can be limited efficiently[18].

The sequence policy of the V4 countries on migration crisis was promoted at the summit of specialists on the Migration Crisis Mechanism January 31, 2017. As a consequence to the decision of Visegrád Group interior ministers, the summit established on 21 November 2016, declared the Mechanism[19].

As the migratory pressure on Europe weakened in the coming months of 2017 , the efforts of the Polish presidency of V4 focused on the priorities in the other areas the Eastern Partnership, cooperation in innovation and digital affairs, the NATO partnership[20]. Nevertheless, the Polish Presidency of the Visegrád Group, in its turn, reported the problems, caused by refugee crisis to the $\mathrm{EU}$, as one of the main issues on which it has focused (on the order of the topics such as the reform and the development of EU and Brexit)[21].

Therefore, the Polish Presidency of V4 showed European partners that this organization is reliable, determined and actively involved in the security of its local aims. Because of the Presidency, Poland was confirmed as high involved and actively participating in V4.

\section{Conclusions}

The analysis of key documents on the migrant issue, adopted during the Polish Presidency of the Visegrád Group, which have an essential influence on the policy of the organization on this topic, allows the concluding of some inferences. First, the activities, connected to the resolving of the crisis, are a leading anteriority of the presidency. In this direction, there is observed a continuity with the previous Czech Presidency, during which the states of V4 strongly disagreed with the quota principle for settlement of refugees. On the contrary, the viewpoint of Poland, Hungary, the Czech Republic and Slovakia stresses the role of the concept of effective solidarity. The discussion on the migration crisis both in V4 and on EU level should be based on it. According to the leaders of Poland, Hungary, the Czech Republic and Slovakia, this programme can be realized in two interrelated ways. Support in the defense of the external borders of the EU (including the Republic of Macedonia) is what the first one intends. The second one consists in support for strengthening of the EU accession in Serbia, Albania and Macedonia, which is supposed to develop the security in Western Balkans.

With a view to the drawn conclusions, the reasons for V4 approach to the migration crisis during the Polish Presidency can be described as adequate, with a view for the next years. Moreover, the position of the German Chancellor partially changed in December. That means that migrants whose refugee status has been rejected or who have been committed as criminals have to be deported. Because of this change, the determined policy of Poland, Hungary, the Czech Republic and Slovakia on the migration issue will develop to its successful consequences.

In 2017, the migration pressure to Europe decreased, which is connected to the sequence policy of the Visegrád Group.

\section{References}

[1] Programme of the Polish Presidency of the Visegrad group 1 July 2016 - 30 June 2017. Ministry of Foreign Affairs, Republic of Poland, Warsaw 2016; Visegrad Bulletin (1/2016), Review of the most important events In July and August 2016. In: http://www.msz.gov.pl/en/foreign policy/europe/visegrad group/polish presidency of the visegrad group $20162017 /$ visegrad bulletin 12016 ;jsessionid=21525D3182 A95EE5D1F7AB7341DCA7BB.cmsap2p; Visegrad Bulletin (2/2016). In: http://www.visegradgroup.eu/visegrad-bulletin-2-2016; Visegrad Bulletin (3/2016). In: http://www.visegradgroup.eu/visegrad-bulletin-3-2016; Joint Statement of V4 Interior 
Ministers on the Establishment of the Migration Crisis Response Mechanism. In: http://www.visegradgroup.eu/calendar/2016/joint-statement-of-v4; The Visegrad Group Joint Statement on the Western Balkans, In:

http://www.visegradgroup.eu/calendar/2016/the-visegrad-group-joint; Visegrad Bulletin 1 (4)/2017. Review of the most important events of the Polish V4 Presidency from December 3rd, 2016 to March 7th, 2017 http://www.msz.gov.pl/en/p/msz_en/foreign_policy/europe/visegrad_group/polish_presi dency of the visegrad group_2016_2017/visegrad bulletin_1_4_2017 - (available on 07.03.2018).

[2] Macdowal, A. Voters back Viktor Orbán`s rejection of EU migrant quotas. In: http://www.politico.eu/article/hungary-referendum-eu-migration-viktor-orban/; Culik, J. Hungary's invalid refugee referendum dents Viktor Orbán's anti-EU 'revolution'. In: https://theconversation.com/hungarys-invalid-refugee-referendum-dents-viktor-orbansanti-eu-revolution-66424 - (available on 02.03.2018).

[3] Programme of the Polish Presidency of the Visegrad group 1 July 2016-30 June 2017. Ministry of Foreign Affairs, Republic of Poland, Warsaw 2016, p.7-8.

[4] Ibid., p.8-9.

[5] Ibid., p.9.

[6] Visegrad Bulletin. Review of the most important events In July and August 2016.

[7] Мариуш Блашчак: Защиттата и укрепването на гранищите на EC са приоритет за Вишеградската груnа. (Mariusz Błaszczak: Protecting and strengthening EU borders are a priority for the Visegrad Group)

http://bnr.bg/post/100714091/zashtitata-i-ukrepvaneto-na-granicite-na-es-sa-prioritetza-vishegradskata-grupa - (available on 25.02.2018).

[8] Xenophobia not being behind the migration policy of the Visegrad Group is evidenced by the fact that the Czech Republic has a relatively large number of permanent and temporary residing foreigners in the country from states outside the EU - nearly 470,000 people, as more than 47000 of them are from Vietnam. See more: Ivanova D. The policy of the Czech Republic on refugees - a manifestation of euroskepticism or national responsibility. - Europa del Este Unida '16,1 Enero-Junio. p. 54-55. http://www.europadelesteunida.com/europa-del-este.html - (available on 02.03.2018).

[9] Visegrad Four gave ultimatums to Brussels https://www.actualno.com/europe/vishegradskata-chetvorka-postavi-ultimatumi-nabruksel-news 563395.html - (available on 01.03.2018).

[10] Резултати от аварийно-спасителната срещца на върха на ЕС в Братислава. (Results from the EU emergency summit in Bratislava). - http://bultimes.com/rezultatiot-avarijno-spasitelnata-sreshta-na-varha-na-es-v-bratislava/ $\quad$ - (available on 02.03.2018).

[11] The referendum is not valid because voters are around $45 \%$, while according to the Hungarian Constitution there must be more than $50 \%$ of voters. See more: Macdowal, A. Op. cit.

[12] Culik, Jan. Hungary's invalid refugee referendum dents Viktor Orbán's antiEU 'revolution'. In: https://theconversation.com/hungarys-invalid-refugee-referendumdents-viktor-orbans-anti-eu-revolution-66424 - (available on 05.03.2018).

[13] Joint Statement of V4 Interior Ministers..., Op. cit.

[14] Visegrad Bulletin (3/2016). Op. cit. - P.2.

[15] Joint Statement of V4 Interior Ministers..., Op. cit. 
[16] Meeting of ministers and representatives of 15 Central and South-Eastern European countries attended by head of European diplomacy. http://www.msz.gov.pl/en/foreign_policy/europe/visegrad_group/polish_presidency of the visegrad group 2016 2017/meeting_of ministers and representatives of 15 ce ntral and south eastern european countries attended by head of european diploma cy;jsessionid $=21830255 \bar{A} 6$ ACE68ECED570CD32F784E2.cmsap2p - (available on 15.02.2018).

[17] The Visegrad Group Joint Statement..., Op. cit.

[18] Joint Statement of the Heads of Governments of the Visegrad Group (V4) countries Brussels, $15 \quad$ December 2016 http://www.msz.gov.pl/en/p/msz en/foreign policy/europe/visegrad group/polish presi dency of the visegrad group 2016 2017/joint statement of the heads of governme nts of the visegrad group $\mathrm{v} 4$ countries brussels 15 december_2016 - (available on 07.03.2018).

[19] Visegrad Bulletin 1 (4)/2017..., Op. cit.

[20] Joint Communiqué of the Visegrad Group Ministers of Defence. Niepołomice, 2 February 2017 - http://www.visegradgroup.eu/documents/official-statements/jointcommunique-of-the; Joint declaration on mutual co-operation in innovation and digital affairs. "Warsaw Declaration”, Warsaw, March 28th, 2017 http://www.msz.gov.pl/en/p/msz_en/foreign_policy/europe/visegrad_group/polish_presi dency of the visegrad group_2016_2017/joint_declaration_on mutual_co_operation in_innovation_and_digital_affairs_warsaw_declaration_FMs of the Visegrad Group and countries in the region discuss the future of the Eastern Partnership, 13.04.2017 http://www.msz.gov.pl/en/p/msz en/foreign_policy/europe/visegrad_group/polish_presi dency_of the visegrad_group_2016_2017/fms_of the visegrad_group_and_countries in the region discuss the future of the eastern partnership; Joint statement of the Prime Ministers of the Visegrad Group on the amendment of Posting of Workers Directive, $\quad 11 \quad$ May 2017

http://www.msz.gov.pl/en/p/msz en/foreign_policy/europe/visegrad_group/polish_presi dency of the visegrad group 2016 2017/joint statement of the prime ministers of the visegrad group on the amendment of posting of workers directive (available on 08.03.2018).

[21] On Friday June 30th, Poland concluded its presidency of the Visegrad Group. The political initiatives presented during the presidency and the strengthening of regional solidarity has helped confirm Poland's active role in Central Europe.

https://poland.pl/politics/foreign-affairs/poland-concludes-one-year-chairmanshipvisegrad-group/ - (available on 08.03.2018). 